\title{
Law Libraries and their Users
}

\section{Introduction}

Law libraries in Britain and Ireland form a distinct and dynamic group within the information world. They are defined by their focus on the discipline and practice of law and their close connection with, and mission to serve, the various parts of the legal system, notably the bar, the courts and the judiciary, solicitors, government, those in professional legal education and those learning the law and researching it as an academic discipline.

Law libraries are a cross-sectoral group, they have parent institutions which range across the private and public spheres but they retain a common identity through their dealings with the legal profession in its various branches and their management of legal information in its various proliferations. Many libraries serve legal institutions directly; some are collections forming part of larger libraries, such as the national libraries and many of the universities. They are diverse in nature and size and the ways in which they seek to provide for their users. Their scope and number have grown enormously in recent years. They include some of the most ancient libraries and the newest information units, repositories of centuries of learning and virtual systems distilling the knowledge bases of extraordinarily successful commercial firms.

Law librarians have responsibility for the selection, acquisition, storage, arrangement, and delivery of material records of legal relevance in convenient and speedy ways suited to the nature of the legal research of their users. In doing this they play a vital part in the administration of justice, in the support of scholarship and legal education, and in the functioning of a social system which adheres to the rule of law.

Law librarians identify themselves as a distinct group within librarianship despite the wide diversity of their libraries and have formed an active and successful professional community. The British and Irish Association of Law Librarians (BIALL) and many other local, regional, and topical associations, successfully sponsor professional development and the promotion of standards, professional collaboration and networking, on a cross-sectoral basis. Law librarianship in the latter part of the twentieth century became and remains a desirable career path, particularly in the commercial sector. Law Libraries have been at the forefront of many developments in information management and are currently at the leading edge of exploring new roles for libraries and librarians in serving their constituencies.

This chapter will describe and set law libraries in context and relate their present state and their historical development to the various branches of the legal profession and the legal system. The chapter will also describe professional collaboration, networking and professional associations of law librarians. A survey of the underlying directions of change and strategic drivers as they affect law libraries concludes the chapter and seeks to give some sense of the future for law libraries. This can only be a brief survey and there is a need to define a research agenda in law librarianship to investigate present practice and inform the redefinition of our profession. 


\section{Role of Law Libraries}

The law has always been information based and information intensive, particularly in common law systems. As organisations seek to harness and derive value from information ever more efficiently, the net for relevant information is thrown more widely, particularly in law firms. Relevant legal information is no longer contained solely in published form or in occasional 'unpublished' judgments. Information may take the form of in-house documentation, expertise, and information deriving from the practice of law and from discrete legal transactions. Many types of information are now drawn into more formal information systems and become intellectual capital within these vigorous competitive environments. This is a road along which other organisations in other sectors, such as universities, are also embarking.

The know-how database on the law firm's intranet and the management of intellectual assets and knowledge in other forms raise questions about the definition of law libraries and the roles of law librarians. This is a fundamental change from the situation described in the first chapters of the predecessors to this work, the two editions of the Manual of Law Librarianship (Daintree, 1976: Logan, 1987), ${ }^{1}$ where the description of libraries could generally be satisfied by reference to libraries in the more traditional sense which dealt for the most part with published sources of information in print acquired from outwith the organisation.

\section{Types of libraries and their users ${ }^{2}$}

Law libraries in Britain and Ireland date from medieval times and were established to serve legal institutions such as the Inns of Court and are closely tied to the development of those institutions. ${ }^{3}$ There were still very few law libraries by the middle of the nineteenth century and they generally served professional organisations of barristers and solicitors and were located in the capital cities.

Since the middle of nineteenth century there has been an enormous growth in all emanations of the legal system. Dramatic reforms of the legal system and the conduct of its business affected different branches of the profession at different times during the period. There is a detailed account of the development of the legal profession in England and Wales until 1988 by Richard Abel who has also written a study of the legal profession in the 1990s

\footnotetext{
${ }^{1}$ The chapters, then as now, were intended to include the historical background to the development of law libraries. There is also an overview of the contemporary state of law libraries by Daintree (1983) and by Miskin (1981) with more emphasis on electronic databases and the future of law libraries.

${ }^{2}$ When published, a chapter by Guy Holborn in the forthcoming History of libraries in Britain and Ireland will provide a detailed and scholarly account of the profession and its libraries between 1850 and 2000. I have had the benefit of a draft (considerably more extended than the version to be published). The chapter (cited hereafter without date as Holborn) as a whole is an invaluable source with detailed bibliography covering similar ground to this chapter, concentrating on the practising profession.

${ }^{3}$ This chapter does not cover personal law libraries.
} 
which was a period of particularly turbulent change (Abel, 1988; Abel, 2003). ${ }^{4}$ The amount of legislation and litigation has increased the potential sources of law dramatically and there has been a growth in legal publishing to try to satisfy an inexorable desire to access more of that law. The impact of other national and international legal regimes and proliferating transnational legal relationships have increased both the quantity and the geographical extent of relevant law. The profession itself has grown and the legal educational systems which offer the routes to join that profession have grown in scope and number. These increases have fuelled the expansion in the numbers of law libraries and the number of law librarians.

The latest edition of the Directory of British and Irish Law Libraries (Fothergill, 2002) has 550 entries, although there are undoubtedly other law libraries which are not listed. Some libraries are listed by virtue of relatively small law collections within a library whose main focus is elsewhere. In terms of geographical dispersal, 417 libraries are listed in England (of which almost half are located in London), 20 in Wales, 62 in Scotland, 10 in Northern Ireland, 33 in Ireland, 3 in the Channel Islands, and 4 in the Isle of Man. The libraries can be analysed by sector which displays their diversity and the current preponderance of libraries serving solicitors. There are 169 law firm libraries (multi-site law firms are counted only once); 7 court / tribunal libraries; 16 in chambers of barristers; 58 special or professional society libraries (including libraries serving the organisations of the bars and of solicitors, both local and national) ${ }^{5}$; 93 academic; 4 parliamentary libraries ${ }^{6} ; 27$ corporate / commercial libraries (including publishers, chambers of commerce and insurance companies); 51 government / local government libraries; national libraries share 6 entries (the BLDSC and the India Office collections merit separate entries); and 81 public libraries.

\section{Libraries serving the bar in England and Wales}

The bar is the branch of the practising legal profession which has enjoyed, until relatively recently, the exclusive right of audience in the higher courts. ${ }^{7}$ This right was conferred on their members since the sixteenth century by the four Inns of Court, independent and unincorporated bodies which developed a

\footnotetext{
${ }^{4}$ Abel (1988) and Abel (2003) both have very extensive bibliographies. See also Hogan (1986) for an earlier history in Ireland. Histories of particular institutions in the various jurisdictions such as the Faculty of Advocates or the Law Society of Ireland are cited below at the appropriate points.

${ }^{5}$ This category also include a variety of other professional bodies whose business involves the law such as accountancy, actuarial work, arbitration, chartered secretaries, insurance, tax, trades unions, and also various international organisations.

${ }^{6}$ These include libraries for the National Assembly for Wales and the Northern Ireland Assembly, and both Houses at Westminster but not yet the Scottish Parliament although that body has arguably made the best provision for the delivery of information about its work through the Scottish Parliament Research and Information Group.

${ }^{7}$ Until the Courts and Legal Services Act 1990 and section 24 of the Law Reform (Miscellaneous Provisions) Scotland Act 1990 began the process throughout the 1990s of removing the exclusive rights of audience. The classification of libraries serving the bar or serving solicitors is a convenience here but is rooted in the history and the current provision of library facilities for the profession.
} 
collegiate form: Gray's Inn, Inner Temple, Middle Temple, and Lincoln's Inn. ${ }^{8}$ They date from medieval times when there was a larger number of inns in existence for those lawyers and others who needed to be in London when Parliament and the courts were in session. These four had reached a predominant position by 1400 and had developed into settled academic establishments. They became the source from which almost every judge was appointed and remain the centre of the barristers' profession. They collectively bear responsibility for the regulation of the profession including matters of discipline, the admission of members, and the required standards of legal education. In physical terms each Inn provides collegiate space in the centre of legal London near to the courts, renting out space as chambers for barristers to conduct their business, and each providing shared facilities and services including, from earliest times, a library.

Practising barristers now number well over 10,000 and almost a third practise outside London. In addition to advocacy, they are primarily concerned with drafting legal documents, writing opinions, advising clients and the preparation of pleadings. The bar has traditionally been termed the senior or learned branch of the legal profession and has for generations provided the opportunity for specialisation and been the source of expertise in particular areas of law.

Over the past fifteen years the threat of competition to the bar from law firms, especially those employing in-house specialists, and increased competition within a rapidly expanding bar has led to fundamental changes within the profession and the modernisation of the running of barrister's chambers and of the Inns. This has included the establishment of libraries, managed by trained staff, within some sets of chambers, building on the personal and shared collections of basic materials located there, and an increased recognition of the importance of the Inn libraries.

The libraries of the four Inns have an age commensurate with their institutions, and although their collections would have been relatively small until the nineteenth century, they grew rapidly from the middle of that century. Holborn tells us that all the Inns erected new buildings for their libraries between 1831 and 1861 and that in 1859 it was estimated that Lincoln's Inn had 30,000 volumes, Inner Temple 18,000 volumes and Middle Temple 15,000 volumes, while Gray's Inn, always the smallest, nonetheless by 1847 assembled the respectable total of 7,500 volumes. In 1850 Lincoln's Inn Library was the largest law library in the common law world. The library buildings of Inner Temple, Middle Temple, and Gray's Inn were destroyed by enemy action during the Second World War, and Gray's Inn also lost all its books. The cost of reinstating the Inns contributed to a state of finances of the Inns which was less than robust for much of the twentieth century until reforms in the later part of that period.

The libraries of the Inns maintain some of the few great collections of foreign

\footnotetext{
${ }^{8}$ http://www.graysinn.org.uk/; http://www.innertemplelibrary.org.uk/; http://www.middletemple.org.uk/; http://www.lincolnsinn.org.uk/
} 
and international law in Britain and Ireland, as well as magnificent collections of English law. Their early establishment ensured that their historical collections of legal materials and manuscripts are extremely rich and, where possible, they still supplement those collections with selected materials when they become available. The scope of the early collections was far wider than law. In common with most society and professional libraries of their age, they collected works of literature, history, topography, travel, biography and similar learned subjects. Much of this remains, though depleted through disposal in recent years.

The libraries of the Inns are private libraries not open to the general public; they serve members of their own Inn, including student members training for admission to the bar, and barristers who have chambers in the Inn and their pupils. Barristers who are members of the other Inns and have chambers elsewhere are also admitted if their own Inn does not hold the material which they seek. Solicitors may be admitted by prior arrangement as a library of last resort for material unavailable in other London law libraries. Scholars are welcomed by appointment to use the rare books, manuscripts, and archives of the Inns. The libraries of the Inns are principally reference collections rather than lending libraries, although lending was always extended to Benchers, those senior members who manage the affairs of their societies, and for the purposes of taking a particular item to court.

The libraries of the Inns now offer automated catalogues ${ }^{9}$ which can all be searched from each Inn, and union lists of current law reports, periodicals and looseleaf services ${ }^{10}$, provide a wide range of electronic services, distance services to members of the provincial bar, collaborate over admission and opening hours, and have a co-operative collection development policy which concentrates provision for particular jurisdictions and subjects. Each Inn library maintains special collections and takes a primary responsibility for collecting the law of jurisdictions of Britain and Ireland in addition to its core collections of the law of England and Wales. ${ }^{11}$ Overall cooperation is within the terms of reference of an Inns of Court Libraries Liaison Committee which reports to the Council of the Inns of Court and Bar. The issue of whether four such fine libraries, representing the heart of four societies with independent identities but carrying out such similar functions can be even more closely combined has yet to be resolved.

\section{Libraries serving the bar in Scotland and Ireland}

Scotland is a separate jurisdiction with a distinct legal system based on Roman civil law whereas the English common law forms the basis of the

\footnotetext{
${ }^{9} \mathrm{http}: / / \mathrm{www}$.innertemplelibrary.org/external.html. The catalogues are available independently. However, Inner Temple regularly uploads the records of the other three Inns into its system providing a combined search. Lincoln's Inn and Gray's Inn produce their catalogue as a joint venture and their combined holdings can be searched together from either library.

${ }_{11}^{10} \mathrm{http}: / / \mathrm{www}$.innertemplelibrary.org.uk/collections/legal-collections/inns-of-court-libraries.htm

${ }^{11}$ Commonwealth law and the law of Scotland in Inner Temple; Commonwealth law and the law of the Isle of Man and the Channel Islands at Lincoln's Inn; United States law, European Union law and the law of Ireland in Middle Temple; and international law and the law of Northern Ireland in Gray's Inn. http://www.innertemplelibrary.org.uk/collections/legalcollections/inns-of-court-libraries.htm
} 
jurisdictions in Ireland. They do, however, share the practical implications of the relatively small size of their legal professions.

The Advocates' Library ${ }^{12}$ in Edinburgh is the private library of the Faculty of Advocates; it was founded in 1689 by a small professional society of lawyers and became a national cultural and intellectual institution; see Cadell \& Matheson (1989), St.Clair \& Craik (1989), and John (1992). In common with many libraries for lawyers it began to develop a general scholarly library. In 1710 it received copyright deposit status and by the nineteenth century it had begun to operate as a national library. This placed a huge burden on the private resources of the Faculty but it discharged them so successfully that, when the situation was resolved in 1925, it transferred by gift three quarters of a million volumes of non-legal holdings to form the National Library of Scotland. From that date, retaining its copyright deposit privilege, it has continued as a dedicated law library, known as the finest working law library in the British Isles, and it possesses the best collection of continental European civil law works in Britain and Ireland and great collections of the papers of judges and advocates relating to court cases. In common with the Law Library system in Dublin it provides the working space and place of business for advocates and the administrative infrastructure to support them.

In Belfast the Bar Council of Northern Ireland operates the Bar Library, which is situated next to the courts and is the base for all practising barristers in Northern Ireland, providing office and other support services as well as library and information services. ${ }^{13}$ In a development similar to that In Dublin, a new Bar Library building was opened in April 2003 while retaining the traditional smaller Bar Library.

The King's Inns ${ }^{14}$ in Dublin is a single society founded in 1541 which has a rather different history from the English Inns; it has played a smaller role in the education of lawyers and is not a central physical focus of the bar (Kenny, 1992). Its library was formed in 1788 when it purchased the library of $\mathrm{Mr}$ Justice Robinson but not properly housed until 1832 when it was established in its present premises in Henrietta Street as part of a new complex of buildings giving the Inns its first dedicated home (Neylon, 1973). The collections developed as a general learned and scholarly library, in common with the English Inns and the libraries serving the profession in Scotland, and "about $40 \%$ of the library's 96,000 volumes are still today non-legal" (Holborn). Although it is an excellent law library, it is not the first resort for the Irish bar since it does not form their place of business.

For over two hundred years the place of business for the bar in Ireland has been at the Four Courts, housed in a magnificent building on the Quays, which provides accommodation both for the courts, ranged around a central Round Hall which has been imitated in other jurisdictions, and for barristers first in the Hall and then in the Law Library. ${ }^{15}$ The Law Library, added in 1834

\footnotetext{
${ }^{12}$ http://www.advocates.org.uk/web/lib1.htm

${ }^{13}$ http://www.barlibrary.com/

14 http://www.kingsinns.ie/

15 http://www.lawlibrary.ie/
} 
and occupying a new east wing from 1897, provides the working desk space, support services, and meeting place for barristers as well as the law collection. The Four Courts was under tremendous pressure for space and in 1998 the Bar Council of Ireland opened its modern facility a hundred yards away from the Four Courts, named the Distillery Building because it is built into the old walls of the Jameson's Distillery. This facility preserves and extends the Law Library way of working, providing desks as office space for barristers alongside a library which houses relatively small book collections but also makes extensive provision for electronic legal research.

\section{Libraries serving the courts and the judiciary}

The Court Service ${ }^{16}$ is currently an executive agency of the Department for Constitutional Affairs and is responsible for the running of most of the courts and tribunals in England and Wales. It provides the necessary services to the judiciary and court users, including library services to the courts and the judiciary in England and Wales. It operates a headquarters and major libraries in London and a regional library and information service with libraries based on the circuit system at Crown Courts and Combined Court Centres in England and Wales. Its institutional context may change in the near future as a result of continuing reforms of government and the courts. Magistrates' Courts and more tribunals are likely to be included in the remit of its Library and Information Services. It is currently developing the national delivery of electronic information to its large constituency.

An organised national library and information service in support of the courts and the judiciary is a recent development. Even the Supreme Court Library in the Royal Courts of Justice is relatively recent, having been established in its present form in 1968, although incorporating several earlier private ventures by the judiciary and the bar; see Best (1983). ${ }^{17}$ The short history and relative paucity of provision for the judiciary is in part explained by the availability of other library resources for judges, notably at their Inn or their own private libraries, but more importantly by the traditions of the English legal system in which judges do not rely on their own legal research but on research by counsel.

The Supreme Court Library in London serves the judiciary and staff of the Court Service and the Department for Constitutional Affairs. A separate branch based on the Bar Library, which had been originally established by the Inns when the Royal Courts of Justice were built in 1884, also admits litigants in person and members of the legal professions to consult material not readily available to them elsewhere. The library maintains extensive collections of transcripts and indexes of transcripts from the Court of Appeal (Civil Division) 1951- and the Court of Appeal (Criminal Division) 1963-1989 as well as from the Employment Appeal Tribunal and the Immigration Appeal Tribunal.

The Appellate Committee of the House of Lords forms the highest court of appeal in the United Kingdom and is composed of professional judges who

\footnotetext{
${ }^{16}$ www.courtservice.gov.uk

${ }^{17}$ The Supreme Court Library incorporates the Chancery Library, later the Probate Library, and the Bar Library
} 
may be drawn from all jurisdictions of the United Kingdom. It is separate from the courts of England and Wales as it also serves Scotland and Northern Ireland. The judges are presently accommodated in the Palace of Westminster and draw on the Palace for the necessary support services including library services. The House of Lords Library was established in 1826 and was primarily devoted to the support of the appellate function of the House and still places considerable emphasis on that function. The library has considerable holdings of the law of England and Wales and Scotland, including early legislation, selected materials from other common law jurisdictions, and collections on legislative drafting and statutory interpretation, European Union law, and human rights (Jones, 1998). Recent government proposals (Constitutional reform ..., 2003) will create a new 'free standing Supreme Court', separating the highest court of appeal for the United Kingdom from the second chamber of the Parliament and the Lords of Appeal in Ordinary from the legislature. This implies a very large-scale investment in the Court's future accommodation and services, not least in the library services.

In Scotland the Supreme Court Library serving the Court of Session and the High Court of Justiciary is located in Parliament House amid a concentration of other law libraries, including of course the Advocates' Library. The Northern Ireland Court Service maintains a library within the Royal Courts of Justice in Belfast and at its headquarters from which is serves the regional courts offices and distributes most of its resources to the chambers of judges.

In Ireland, the Judges' Library within the Four Courts, comprising about 20,000 volumes, provides the main service to the judiciary of the High Court and the Supreme Court and various branches of the administration of the court system, and also at a distance to judges of the District and Circuit Courts (Donnelly, 1996). The King's Inns Library also serves as a resource for the judiciary.

\section{Libraries for solicitors in England and Wales}

There are about 100,000 solicitors in England and Wales. The majority of solicitors' firms are distributed around the country and their business mainly comprises conveyancing, probate, family, employment and social welfare law. The profession in England and Wales first made provision for libraries not nationally but in the context of the formation of local law societies outside London in the late eighteenth and early nineteenth centuries, including Bristol $^{18}$, Yorkshire, Manchester ${ }^{19}$, Plymouth and Birmingham. ${ }^{20}$ These and many others ${ }^{21}$ are independent non-profit organisations which do not form part of the Law Society of England and Wales; libraries often figured

\footnotetext{
${ }^{18} \mathrm{http}: / / \mathrm{www}$. bristollawsociety.com/

${ }^{19}$ The Manchester Law Library serves and lends to both solicitors and barristers http://www.manchester-law-library.co.uk/

${ }_{20} \mathrm{http}: / /$ www.birminghamlawsociety.co.uk/

${ }^{21}$ Links to the websites of 25 such local law societies can be found on the Law Society of England and Wales website
} 
prominently in their original objectives ${ }^{22}$ and still provide valuable services to their members (Martin, 2001).

The Law Society of England and Wales ${ }^{23}$ is the professional body for solicitors, established in Chancery Lane in London since 1831, some time later than some of the local law societies, and operating a library from the time of its establishment. The Law Society was granted a Royal Charter in 1843 to regulate the profession. In common with the other professional libraries it amassed considerable collections of non-legal materials but most of these have been disposed of over the past twenty years. The library maintains extensive working collections of the law of England and Wales, fine historical collections, and runs the European Union Legal Information Service, acting as a 'sectoral information relay' recognised by the European Commission (Smith, 2000). Services to all solicitors, in larger firms in London and in practices around the country, include enquiry services and a speedy document delivery service.

The largest and most well established library services are found in law firms in and around the City of London which are extremely large and successful global businesses. The largest law firm currently has over 600 partners and 3300 fee-earners worldwide, employs 7,000 staff, and fee income can be measured in hundreds of millions of pounds. Nationally some firms in metropolitan areas outside London have grown large enough to deal with large-scale commercial business or have formed groups and consortia to do so. These law firms are at the leading edge of law library development in the broadest sense; they invest heavily in information management both in terms of information itself, technology to store and manipulate it, and in professional skills to devise and implement information and knowledge management strategy.

The large increase in professional law library jobs since the early 1970s when the first professional law librarians were appointed in law firms can be attributed to the growth of these large law firms. The removal of the restriction in the number of partners to 20 by s. 120 of the Companies Act 1967 was a major factor in the dramatic expansion in the size of law firms as they grew with the growth of financial and commercial activity in the City of London. In 1976 , in an earlier edition of this work, the existence of a small number of libraries in solicitors' firm was noted, "in some cases a librarian has been appointed to exploit these materials..." (Daintree, 1976, pp. 50-51). By 1984 there were 34 private practice libraries in the Directory of Law Libraries in the British Isles and, as noted above, there are 169 in the latest edition; over half of the members of BIALL are employed in law firms.

\section{Libraries for solicitors in Scotland}

The Law Society of Scotland ${ }^{24}$ was created by statute only in 1949 but the formal organisation of lawyers who were not advocates and came to be called

\footnotetext{
${ }^{22}$ In the same way as 'law library associations' sprang up in the United States during the same period; see Pound (1953) pp. 215-219

${ }^{23} \mathrm{http}: / /$ www.lawsoc.org.uk/

${ }^{24} \mathrm{http}: / /$ www.lawscot.org.uk/
} 
solicitors began much earlier.

The Society of Writers to His Majesty's Signet (WS ${ }^{25}$ dates from the middle ages and remains a private society of lawyers in general legal practice; the acronym WS appears after members' names. The Signet was the private seal of the early Scottish Kings, and the Writers to the Signet were those authorised to supervise its use and, later, to act as clerks to the Courts. The Society took definite shape in 1594, when the King's Secretary, as Keeper of the Signet, granted Commissions to a Deputy Keeper and eighteen other writers.

The WS Society is particularly noted for its ownership of the Signet Library, whose history from 1722 has been fully chronicled by George Ballantyne in 1979 with a briefer account in 1971. The Signet Library is now housed in one of the finest Georgian buildings in Scotland which originally comprised a Lower Library for the Society, completed in 1815, and an Upper Library for the Faculty of Advocates, completed in 1822. The Faculty of Advocates moved to a newly constructed building soon after and the Society linked the Upper and Lower libraries. From the late eighteenth century and early nineteenth century the library expanded greatly and, in similar fashion to the Advocates' Library, broadened its collections beyond law, and made its library available to general readers. The burden on a small society proved too much and, after increasing financial constraints, a period of contraction and sales began in 1958 and continued until 1979. In 1879 the library had contained about 65,000 volumes, at the turn of that century over 100,000 books, and today it again contains about 65,000 , of which almost half are legal and, of the rest, about 20,000 are of historical and topographical interest devoted mainly to Scotland.

The other national society in Scotland is the Society of Solicitors to the Supreme Court (the SSC Society), ${ }^{26}$ which was formed in 1784 and is incorporated by Royal Charter. It is located in Parliament House in Edinburgh and continues to play a central role in the life and work of the Courts of Scotland and the legal profession generally. Membership is open to all solicitors who are members of the Law Society of Scotland but is mostly drawn from those involved in the conduct of litigation in the Court of Session, the High Court of Justiciary and Sherriff Courts throughout Scotland. The Library of the Society is a private library with particular collections of Scottish law as well as UK and European Union law.

Larger firms in the major cities operate their own libraries and nineteen are listed in the latest Directory. Practitioners in the lower courts with local practices, called procurators, formed their own local organisations with rather more powers in regulating the profession that the local law societies in England. The two remaining societies with libraries are the Royal Faculty of Procurators in Glasgow ${ }^{27}$ and the Society of Advocates in Aberdeen, both founded in the second half of the seventeenth century. Although both organisations sold collections in the second half of the twentieth century, they

\footnotetext{
${ }^{25}$ http://www.thewss.co.uk/

${ }^{26}$ http://www.ssclibrary.co.uk/

${ }^{27}$ http://www.rfpg.org/
} 
both maintain significant libraries and that in Glasgow is 'the largest law library in the west of Scotland'. ${ }^{28}$

\section{Libraries for solicitors in Ireland}

The recent scholarly history of the Law Society of Ireland ${ }^{29}$ provides considerable information about the profession (Hall \& Hogan, 2002), and about the Law Society library (Byrne, 2002). The Society, originally granted a charter in 1852 as the Society of Attorneys and Solicitors in Ireland, existed in an earlier form since at least 1830. It is the professional body which educates, regulates and represents solicitors in Ireland. The Society and its library were provided with premises in the Solicitors' Buildings in the Four Courts by the Benchers of King's Inns, which governed the solicitors' profession until 1866. The library and its contents of approximately 3,000 volumes were destroyed in 1922 but the losses had been recouped by 1931 when the Society moved back into the rebuilt Four Courts complex. The Society moved from there to its present premises in Blackhall Place which opened in 1978. In 2000 the Society opened a new library serving members and students in conjunction with its new educational centre on the same site. In 2002 there were almost 6,500 solicitors in 1,956 practices as potential users of the library. "Small to medium-size firms are the heaviest users although the largest firms who in recent decades have developed their own in-house information services are also regular users." (Byrne, 2002, p. 208). Eight law firm libraries in Ireland are listed in the Directory of British and Irish Law Libraries (Fothergill, 2002).

The Law Society of Northern Ireland ${ }^{30}$ was set up under Royal Charter in 1922 and its library provides a range of services to approximately 1,850 solicitors currently practising in Northern Ireland.

\section{Legal education}

The early history of legal education in England is described briefly by Baker (2002) in An introduction to English Legal History. ${ }^{31}$ The relatively modern origins of our current systems of legal education should be appreciated. Following a long decline, by 1850 professional legal education was completely moribund and academic legal education other than in the field of Roman law was virtually non-existent. Even the House of Commons Select Committee on Legal Education could report in 1846, "no legal education worthy of the name is at this moment to be had either in England or Ireland"

The recent history of legal education has not yet been fully documented. Reference can be made to the periodic official reviews touching legal education such as the Ormrod Report (Committee on Legal Education, 1971), the Benson Report (Royal Commission on Legal Services, 1979), the Marre Report (Committee on the Future of the Legal Profession, 1988) and the reports of the Lord Chancellor's Advisory Committee on Legal Education and Conduct in the 1990s together with the studies which they commissioned

\footnotetext{
${ }^{28}$ http://www.rfpg.org/library.html

${ }^{29}$ http://www.lawsociety.ie/

${ }^{30}$ http://www.lawsoc-ni.org/

${ }^{31}$ Baker (2002) includes a brief bibliography on legal education particularly relating to early times and to the establishment of the chairs at Oxford and Cambridge
} 
(Lord Chancellor's Advisory Committee..., 1996). These reviews generally concentrate on education for the legal profession rather than law as an academic discipline.

A useful current summary of legal education and the routes to professional qualification in England and Wales, Scotland, and Northern Ireland, with links to relevant websites is provided by the UK Centre for Legal Education. ${ }^{32}$

In England and Wales, legal education is in three stages: academic, vocational, and apprenticeship. One might now add continuing professional development. There has been scepticism among the practising profession in the past about the relevance of academic study of law as a preparation for practice. In 1883 Dicey gave an inaugural lecture at All Souls College entitled: 'Can English law be taught at the universities?' (Dicey, 1883). He suggested that a body of eminent counsel would reply with unanimity "that English law must be learned and cannot be taught, and the only places where it can be learned are the law courts or chambers".

The existence of an 'academic' stage within the universities which is properly academic is now accepted. However, the tension between the vocational and the academic roles of university law schools, between the notion of the 'trade school' and the academic faculty has not been wholly left behind. The past dominance of the practising legal profession, particularly the Bar, in legal training and education has limited the role of university law schools. The syllabus of a qualifying law degree is still the subject of considerable discussion between the academic branch of the profession and the professional bodies which monitor the syllabus on a subject by subject basis and allow exemptions from the professional examinations for 'core subjects' taught at the academic stage.

Unlike the situation in other jurisdictions of Britain and Ireland, the vocational stage in England and Wales does not attract public funding and has for most of its history been conducted by privately financed and professional law schools outside the university system. The main interest groups have failed to agree an integrated and unified system of legal education which would operate within the scope of public funding. The recent franchising of the legal practice course and the bar vocational course to be taught by individual universities has not changed that essential framework.

\section{University law schools}

The universities from earliest times taught civil and canon law but there was no formal and comprehensive system of education in the common law for much of its history. Blackstone's lectures at Oxford in the 1750s, were primarily not for professional law students but for country gentlemen and clergymen. The publication of the lectures as the Commentaries in 1765-69 has a history of its own in terms of the understanding and the spread of the common law. However, the lectures and the subsequent endowment of the Vinerian chair in 1758 did not firmly establish the study of English law. During

\footnotetext{
${ }^{32}$ http://www.ukcle.ac.uk/directory/index.html
} 
the next fifty years similar chairs were established at Trinity College Dublin and at Cambridge (the Downing Chair in English Law in 1800). The establishment of the law school at University College London in 1826 was a radical departure in many ways as it was the first university in England to admit students of any race, class or religion and the first to welcome women on equal terms with men. Law departments were subsequently established at Queen's College Birmingham in 1850 (Pue,1989), at Owen College Manchester in 1880 and at University College Liverpool in $1892 .^{33}$

The Society of Public Teachers of Law (SPTL), now the Society of Legal Scholars (SLS), held its first meeting in 1909 by which time the President, Henry Goudy, could speak in his introductory address of the reforms in legal education in Oxford and Cambridge, "the recent organization of legal studies in the metropolis both by the Inns of Court and the Law Society, ... the prospects for the future development of a great Law Faculty in connection with the University of London, ... the Schools of Law in the new universities in the provinces ... seven in number." (Goudy, 1909).

A few years later the SPTL published a small booklet of legal curricula at 'various centres of public legal education in England and Wales'; it listed the Universities of Oxford, Cambridge, London, Manchester, Liverpool, Leeds, Sheffield, and Wales, and also the Council of Legal Education, the Law Society, and eight Boards of Legal Studies which prepared students for the qualifying examinations of the Law Society (SPTL, [no date]). ${ }^{34}$ These Boards formed a focus for the collaboration of local law societies and universities in legal education. The Law Society had begun to provide grants to local law societies in the provinces in the late nineteenth century and, after the introduction of the compulsory one-year course in 1922 (the 'academic' or 'statutory' year), it gave grants directly to universities to teach the course until 1962. The provincial law faculties in universities were formally established or grew from this initiative and still continue a local cooperation with practitioners. A brief account of law teaching in many colleges, some of which were to become polytechnics, and in time 'new universities', can be found in $A$ history of the Association of Law Teachers (Marsh, 1990).

University law schools were not the only, or even the preferred, route into the profession until relatively recently. Many distinguished lawyers of the period from 1850 to 1950 were not graduates or were graduates in other subjects and there was a persistent view that members of the bar, as members of a liberal profession, should be graduates in the humanities or other subjects and add law through vocational training at a professional law school at a later date.

Law is now a graduate profession and the law degree is generally the route for those intending to qualify as lawyers. The UK Centre for Legal Education

\footnotetext{
${ }^{33}$ The situation can be compared with legal education in the USA of the period, see Stevens (1983)

${ }^{34}$ The 'Boards of Legal Studies' were variously constituted but generally comprised representatives of the local university, the local law societies, and individual solicitors and barristers practising in the district.
} 
currently lists 92 university law schools in England and Wales, Scotland and Northern Ireland and provides a directory of the law courses which they provide $^{35}$. According to official statistics ${ }^{36}$ there were 77,680 law students in higher education in the UK in 2002/03 of whom 45,665 were female.

Undergraduates numbered nearly 54,000 compared to about 1500 in 1938-39 (62 per cent at Oxbridge). In common with most subjects, there has been an increase in part-time study and distance learning.

The SPTL and the Association of Law Teachers (ALT), whose existence as two organisations still reflects their origins on the two sides of the binary divide, have both published surveys of legal education: Wilson (1966), Wilson \& Marsh (1975), Wilson (1993), Harris \& Bellerby (1993). The description and analysis in Blackstone's Tower: the English law school by William Twining (1994) is essential reading and one might add What are law schools for? (Birks, 1996).

The study of law has in recent years become broader and more diverse and has grown to value other disciplines in its study and begun to produce truly inter-disciplinary study and research. ${ }^{37}$ In common with most subjects there was a dramatic growth in the number of postgraduate students in law since the 1960s and an even faster growth since the 1980s in numbers of students reading for master's degree courses in specialised legal topics. In 2002-03, there were nearly 24,000 postgraduate law students in the UK including master's degree and doctoral students and those in vocational courses taught at universities; 255 PhDs were awarded in law in the UK. Much research in law includes a comparative element and this study grew at a fast pace in the second half of the twentieth century through the effects of the move to the UK of eminent legal scholars from continental Europe, the establishment of new international legal and economic orders, and all the effects of changes usually now swept up in the term globalisation. The effects of the interdisciplinary patterns of study associated with socio-legal studies ${ }^{38}$ have had a profound impact on legal research. An 'inquiry on empirical research in law' was launched in 2003. ${ }^{39}$ These developments will continue to have a direct impact on the range of library resources required.

\section{Academic Law Libraries}

The law library remains a crucial resource in legal education. University law libraries in Britain and Ireland have been well documented in recent years. In an admirable collaboration, the SLS and BIALL have carried out an annual survey of academic law libraries. This replaced a long-running annual survey of expenditure on legal materials in academic law libraries carried out by

\footnotetext{
${ }^{35} \mathrm{http}: / /$ www.law.warwick.ac.uk/lcc/lawschools.html

${ }^{36}$ From the Higher Education Statistics Agency at http://www.hesa.ac.uk

${ }^{37}$ Although "We have not quite reached the point where the law is once again seen as one of the great humane subjects, along with history and literature, as it was in classical and medieval times,..." (Twining, 1994, p.13)

${ }^{38}$ The Socio-Legal Studies Association (SLSA) provides a description of the nature of sociolegal studies on its website at http://www.kent.ac.uk/slsa/

${ }^{39}$ http://www.ucl.ac.uk/laws/genn/empirical/index.shtml
} 
BIALL and published in The Law Librarian. A report of the findings of each survey appears in Legal Information Management.

The report of the 2001/02 survey of academic law libraries (Clinch, 2003) ${ }^{40}$ is based on 87 returns from a possible 104 law libraries. The survey shows considerable diversity but gives a picture at the median of a typical law school with 665 students, in a separate location or shelved as a single identifiable unit, with one seat and also one computer workstation for every four students, open for 74 hours per week in term and 42.5 hours in vacation, spending $£ 75,000$ each year on legal materials (about $£ 126$ per student) including a little over $£ 8,000$ each year on provision of web-based legal databases, and 1.5 library staff with law service as their principal or sole function. A large number of law schools contribute towards the maintenance of the library resource and on average a typical law school provides $£ 13,500$ each year towards library funds. The analysis which appears in the report of these and other figures shows the considerable diversity concealed by these averages, particularly between types of institution such as 'old universities' and 'new universities'.

Academic law libraries generally provide for undergraduate students of law and also may support students of law as part of a non-law degree. Those universities which run vocational courses also make specific provision for their support. Academic law libraries often now support students on taught courses at Master's degree level in certain specialised subjects which are an area of dynamic growth in law schools. Many law schools register students for research degrees in areas of particular expertise of their staff and the library has a responsibility to support their research along with the research needs of their academic staff, although this may well include recourse to other law libraries, regionally or nationally. The university law library may well be the largest law library in the area and may well come to arrangements with readers other than those for whom it is funded, perhaps on payment of a fee, in order to support the needs of local practitioners and others.

Academic law librarians are likely to be more involved in the mission of the law school than ever before, to place greater emphasis on skills training, to be actively engaged in the teaching of information skills and themselves to be formally acquiring teaching skills, to be involved in the management, organisation and delivery of electronic information locally and at a distance, perhaps be collaborating in the construction a portal or a virtual learning or research environment, and be assisting in the selection and administration not only of information products but also their delivery mechanisms.

The law library as a physical place in universities is still important even though a great deal of legal information is now delivered remotely in electronic form. Recent data suggests that in $44 \%$ of libraries numbers of visits have remained constant and in 35\% visits have increased (Clinch, 2003, p. 110). Law libraries have traditionally been used intensively and required the highest ratio

\footnotetext{
${ }^{40}$ Clinch (2003) gives the references for the previous survey reports which form a considerable body of data over time.
} 
of seats to students of any subject. There has also been some controversy in the past in the location of law libraries, whether in the law school or in an identifiable area within the main university library or interspersed among materials of other subjects. The previous edition of this book devoted a section to 'centralization versus decentralization'. The scope of legal studies is increasingly interdisciplinary and requires reference to materials relevant to other subjects although intensive use of core legal materials has not lessened. Current practice appears to show a third of academic law libraries are in a separate location, a third are not separated from the main university library but are in a single identifiable unit, and in 15 per cent of academic law libraries materials are dispersed wholly or partly among other subject collections.

Although all academic law libraries may excel for the purpose for which they are designed, three libraries are outstanding in terms of their research collections, particularly of foreign, comparative and international law, and for their facilities: the Bodleian Law Library at the University of Oxford, ${ }^{41}$ the Squire Law Library at the University of Cambridge, ${ }^{42}$ and the Institute of Advanced Legal Studies at the University of London. ${ }^{43}$ Representatives of the three libraries contributed to a Symposium on Law Libraries (Symposium..., 1964) to mark the opening of the new Bodleian Law Library building designed by Sir Leslie Martin in 1964. The Institute of Advanced Legal Studies was installed in a new building designed by Sir Denys Lasdun in 1976 and most recently the Squire Law Library moved to the new Faculty of Law building by Sir Norman Foster in 1995. The Librarians of the three libraries appeared together, with a representative of the British Library, at the Joint Study Institute in Cambridge in 1998. They each spoke about collaboration in a national context (National legal collections, 1999) and soon after that the successful bid was launched for the Foreign Law Guide project, FLAG (see below).

The Bodleian Law Library holds the largest collections of law of any academic library in Britain and Ireland; it receives all law books deposited under the terms of the Copyright Act because it is administratively part of the Bodleian Library. All stock is on open access in a classified arrangement which renders the copyright deposit material much more accessible than material housed in the national libraries. "The Codrington Library at All Souls College also has a fine law collection which often supplements the Bodleian in respect of older material." (Logan, 1987, p.25).

The Squire Law Library of the University of Cambridge has outstanding collections, particularly in international law, but its activities were constrained for a period until its recent move by inadequate accommodation and less than generous staffing and funding. The Radzinowicz Library ${ }^{44}$ of the Institute of Criminology at the University of Cambridge was founded in 1960 and has the

\footnotetext{
${ }^{41}$ http://www.bodley.ox.ac.uk/dept/law/

42 http://www.law.cam.ac.uk/squire/

${ }^{43} \mathrm{http}: / /$ www.ials.sas.ac.uk/library/library.htm

${ }^{44}$ http://www.crim.cam.ac.uk/library/
} 
most comprehensive collections in its subject in the United Kingdom and is soon to have new accommodation alongside the Faculty of Law building.

The library of the Institute of Advanced Legal Studies (IALS) of the University of London performs many of the functions of a national legal research library and has a formal collaboration with the British Library. ${ }^{45}$ The principle of cooperation on a national basis has always been at the heart of the IALS Library. Its primary constituency comprises the national academic legal research community and it admits postgraduate research students and academic staff from any university worldwide. It is also the postgraduate research law library of the University of London and forms the most prominent part of a network of law provision within the University, whose law-teaching colleges (Birkbeck College ${ }^{46}$, King's College London, the London School of Economics, Queen Mary University of London, the School of Oriental and African Studies, and University College London) each have significant research collections in addition to their undergraduate provision.

Although established in 1947, the IALS Library is the second largest legal research library in the UK in terms of collections with over 300,000 volumes and has the largest law library staff of any academic law library in Europe. It plays a significant role in the training of law librarians. The library was well known for its printed bibliographical works including union lists and the Index to Foreign Legal Periodicals. Recently it is known better for its electronic publications such as the law content of the Social Science Information Gateway, ${ }^{47}$ producing the Current Legal Research Topics database, ${ }^{48}$ Current Awareness for Legal Information Managers, ${ }^{49}$ and hosting the British and Irish Legal Information Institute, BAILII. ${ }^{50}$

The IALS library is used, on a fee-paying basis, by members of the practising profession and by government and the judiciary. The library also operates a premium information and document delivery service and subscribers include many of the largest law firms and sets of chambers, both Houses of Parliament, the Court Service, various government departments, and overseas institutions. The service was introduced on the basis of full cost recovery after a review chaired by Sir Robert Megarry, recognising the duty of the Institute to the profession, as a matter of public interest and as a contribution to the administration of justice (IALS, 1986).

In Scotland, nine universities offer the Bachelor of Laws degree, either as an ordinary degree over three years or as an honours degree over four years. . The institutions and their libraries vary in size and age but include some of the oldest university institutions in Britain and their libraries also vary in size and scope and degree of separateness from the main university library system.

\footnotetext{
${ }^{45}$ http://ials.sas.ac.uk/flare/flare_origins.htm

${ }^{46}$ Birkbeck College School of Law teaches law and carries out legal research but does not have extensive legal research collections in its college library.

47 http://www.sosig.ac.uk/

${ }^{48}$ http://193.62.18.223/library/clrt/clrt.htm

${ }^{49}$ http://www.ials.sas.ac.uk/library/caware/caware.htm

${ }^{50}$ http://www.bailii.org/
} 
The extensive law library at Edinburgh University comprising over 60,000 volumes is in separate accommodation alongside the Europa library containing the European Documentation Centre. As Scots law is a mixed legal system of civil law drawing on elements of common law, collections are likely to be stronger in civil law, Roman law, as well as the institutional writers of Scots law, than elsewhere in Britain and Ireland.

In Northern Ireland Queen's University Belfast has the outstanding collection of law housed within the main library. The School of Law of the University has contributed to access to law in other ways through the Servicing the Legal System ${ }^{51}$ programme which is the only regular publisher on Northern Ireland law.

In Ireland there are five universities teaching law of which Trinity College Dublin has the most extensive collections of law and receives publications on copyright deposit both from Ireland and the United Kingdom., The Law Faculty at University College Cork hosts the Irish Legal Information Initiative ${ }^{52}$ which complements the British and Irish Legal Information Institute.

\section{Libraries supporting professional legal education}

The Inns of Court and Chancery were once known as the third university of England and the early history of their role as teaching institutions is described by John Baker (Baker, 2000). By the early fifteenth century an academic community had been established. An elaborate system readings (lectures) and moots developed which provided for the instruction of aspiring barristers, but the English Civil War effectively killed it off in the seventeenth century. The primary means of education in the common law for lawyers was self-help and attendance at the courts and lawyers' offices in London and the discipline and regulation of the profession was lax. Many lawyers until at least the middle of the nineteenth century, rather than study civil law at the universities, would read other subjects prior to their professional training, a tradition in England that lasted long beyond the establishment of modern law schools.

As university law schools began to teach the common law in the midnineteenth century, so the Inns revived their lectures and the Law Society began a course of lectures for articled clerks. The Council of Legal Education (CLE) was established by the Inns in 1856 and a compulsory bar examination was introduced in 1872. In 1967 the CLE opened the Inns of Court School of Law (ICSL) near Gray's Inn as the principal place of education for the vocational stage of training for the bar. In 1997 the Council ceased to operate $^{53}$ and transferred many of its responsibilities to the ICSL which in 2000 merged with the Department of Law of City University. The Bar Vocational Course (BVC) is now taught by several institutions in England and Wales including the ICSL and universities. The College of Law, at several sites in England, was the body set up by the Law Society to teach and administer the vocational stage of education to qualify as a solicitor. A

\footnotetext{
${ }^{51}$ http://www.sls.qub.ac.uk/

52 http://www.ucc.ie/law/irlii/

${ }^{53}$ Records of the Council of Legal Education were deposited at the Institute of Advanced Legal Studies Library, http://www.ials.sas.ac.uk/library/archives/cle.htm
} 
development similar to the arrangements for the BVC has taken place, and the Legal Practice Course (LPC) is taught by the College of Law and by several universities, mainly the new universities, as well as the ICSL. Other professional awards such as the Common Professional Examination or Institute of Legal Executives qualification are usually taught by the same institutions.

Institutions offering the BVC and the LPC have to meet a range of requirements in order to be validated including the provision of particular library facilities which are monitored and assessed by means of a programme of visits by an expert panel. Several universities maintain collections and facilities separate from their university law library to support the courses. The ICSL first opened a library in 1997, having formerly relied on the Inns of Court libraries, and opened a new Legal Training Resources Centre in 2002 with considerable emphasis on networked information services. The four Inns of Court libraries admit student members of their own Inn.

In Scotland and Northern Ireland vocational training remains within the university system, and within the public funding system, and library services are combined with the university systems. After completion of the LLB Degree or professional examinations, intending solicitors and advocates take the Diploma in Legal Practice, which is of 26 weeks duration, at the universities of Aberdeen, Dundee, Edinburgh or the Glasgow Graduate School of Law, which is run jointly by the Universities of Strathclyde and Glasgow. In Northern Ireland the Institute of Professional Legal Practice was established at Queen's University Belfast to offer vocational training to trainee barristers and trainee solicitors. In Ireland, the Law School of King's Inns, whose library has already been described, administers the one-year vocational course somewhat confusingly called the 'degree course' for admission to the bar. The Education Department of the Law Society of Ireland comprises the Law School which runs courses for those intending to become solicitors; their new combined education and library has been described above.

\section{National Libraries}

The national libraries are generally more suitable as a supplementary resource for particular materials rather than a first choice for legal research.

The British Library has very extensive collections of law books and official publications, including some of the founding collections of the British Museum Library, and it benefits from copyright deposit of publications from both Britain and Ireland (Cheffins, 1999). It has particularly strong collections of legal history. However, the British Library has never been able to offer a legal research library service for foreign, comparative and international law and the United Kingdom has never had the equivalent of the Law Library of Congress in the United States (Law Library of Congress, 1982). In the British Library, no one person has overall responsibility for acquisition of legal publications, rather they are acquired by the language sections, other than those handled by the Legal Deposit Office or the Overseas English Section. The law books in the British Library are not arranged as a law library and have no unity as a collection. Access to the collection is through the Social Policy Information 
Service, as part of official publications and social sciences provision, which operates a reading area containing an English law collection. Until very recently staffing did not include a legally qualified librarian or a trained law librarian even at junior level. A review of social science, including law, provision is currently being undertaken at the British Library.

The British Library has for many years co-operated with the nearby Institute of Advanced Legal Studies rather than try to emulate the depth of expertise and collections there. Collaboration with existing centres of excellence was advocated, among other improvements, by the SPTL in their evidence to the National Libraries Committee in 1968 (SPTL, 1968) and elaborated by the British Library Working Party on Provision for Law whose chair was the Director of the IALS and whose Secretary was the Librarian of IALS in the early 1980s (British Library Working Party, [1985?]). The recommendations of the later were not implemented because central funding for the collaborative mechanisms was not forthcoming.

The British Library has recently has entered into a collaborative agreement with the IALS regarding services and collections. Some enquiries are referred to the IALS, staff training at the Institute is now attended by selected British Library staff, and there is active investigation of gaps and overlaps in provision. Collaboration has increased through the British Library's participation in the FLAG project and the more recent establishment of the FLARE partnership led by the IALS. This provides a means, if funds are forthcoming, for the great academic law libraries in Oxford, Cambridge, and London to collaborate with the national library.

The National Library of Scotland is in a unique position since it was created through the transfer of collections from the Advocates' Library described above. There are arrangements to facilitate the consultation by members of the public in the National Library of the legal materials which are retained by the Advocates' Library. The National Library of Wales receives UK copyright deposit material. The National Library of Ireland receives copyright deposit of Irish publications and naturally holds a good collection of Irish law. However, it should be noted that Trinity College Dublin receives both British and Irish publications by copyright deposit.

\section{Public Libraries}

Generally law collections in public libraries in Britain and Ireland are limited to basic collections of the law of the local jurisdiction and European Union law, with an emphasis on official publications; they do not provide sufficient resources for in-depth legal research. Little comprehensive information had been collected about law collections in public libraries at the time of the previous edition of this book and little is available now. It is thought that legal enquiries in public reference libraries do not form a significant percentage of all enquiries numerically but form a large proportion of complex enquiries which take more that ten minutes of staff time to answer. Enquiries from the public provide difficult challenges in guidance and recommendation of materials while avoiding communicating legal advice. Public libraries face considerable difficulties in maintaining collections of law in the face of 
declining budgets, price inflation on legal materials, and difficulties in training staff adequately to perform legal reference work.

In London English law collections can be found at the Westminster Reference Library ${ }^{54}$, at Holborn Reference Library despite moves to close the library in the recent past, at Hammersmith Reference Library by reason of an earlier allocation of law under the LASER (London and South East Region) subject specialisation scheme among public libraries, and at the Guildhall Library which realistically warns that it is not a law library although it holds a collection of English law and 'our files of English law reports are the most extensive likely to be found outside a specialist library'. Central reference libraries of public library systems such as Birmingham, Manchester, Liverpool, and Sheffield have a collection of law for the public and to support local government.

In a paper from BIALL to the Library and Information Services Council in 1985 , it was noted that "perhaps because of the complexity of the literature and the absence of staff trained in its use, the standard of collections and level of legal reference service in public libraries is so abysmally low (with one or two honourable exceptions) as to be useless" (BIALL, 1985). Very little research is available on actual provision of legal information by public libraries. A detailed study of access to legal information in East Kilbride, Glasgow, and Paisley in 1997 did not go so far as the BIALL criticism (Mansfield, 1997). The study nevertheless found that legal collections were out of date and basic in nature, collection development lacked a customerfocus, and training in legal reference work was woefully inadequate.

In part, but only in part, provision of legal information to the public has been overtaken by e-government initiatives. The United Kingdom government, somewhat later than in some other countries, has accepted that the statutes and other products of our democratic system should be made freely available on the Internet. The range of government and non-profit initiatives to make legal material on the Internet without charge is detailed elsewhere.

Government initiatives to publish legal materials on the Internet in both the UK and Ireland form part of a larger agenda to make available national and local government services online. ${ }^{55}$ However, although digital technology offers the possibility of making legal texts available to the general public, legal materials remain complex to retrieve and even more complex to read and interpret.

\section{Parliamentary Libraries}

In many countries the parliamentary library holds one of the most significant legal collections; in some countries the parliamentary library is combined with the national library. The Law Library of Congress in the United States is the largest law library in the country and holds very extensive collections of foreign law. The parliamentary libraries in Britain and Ireland do not have legal collections of a similar scale and do not have large similar collections of

\footnotetext{
${ }^{54}$ http://www.westminster.gov.uk/libraries/special/law.cfm

${ }^{55}$ The UK programme is co-ordinated by the e-Government Unit, http://egovernment.cabinetoffice.gov.uk and exemplified by http://www.direct.gov.uk or in Ireland by OASIS (Online Access to Services, Information and Support) at http://www.oasis.gov.ie/
} 
foreign law but nevertheless do hold good collections of domestic and European Union law to serve legislators, among much broader collections.

The House of Commons Library and the House of Lords Library are both within the Palace of Westminster. The House of Lords Library has more extensive holdings of law since one of its main roles has been to serve the Appellate I Committee of the House which sits as the highest court of Appeal in the United Kingdom. The 'Law Lords' also sit as members of the legislature at present, although reform of the House of Lords may in future prevent their participation (Constitutional reform, 2003). The House of Common Library contains legal materials, with some emphasis on statutory law, for Members of Parliament and the considerable body of research officers serving them. The POLIS database of parliamentary business is maintained by the Library. The public are not admitted to the libraries and, in general, enquiries should be directed to the House of Commons Information Office or the House of Lords Information Office, although the House of Lords Library responds to research enquiries regarding unique historical materials held there. The House of Commons Information Office also produces useful fact sheets and a Weekly Information Bulletin of activities of the House while in session, and various other materials, all available in full text on the Parliament website. ${ }^{56}$ The website itself now has extensive information about the workings of Parliament including the full text of Hansard, the record of proceedings of Parliament, back to November 1988, and even live television of the debates via the Internet.

The Scottish Parliament, the National Assembly for Wales, and the Northern Ireland Assembly (currently suspended), which form the devolved parliaments and assemblies in the United Kingdom have information services, whose coverage naturally include law, for their members. They also place considerable emphasis on information to the public. The Scottish Parliament Information Service Centre, for example, provides research and information services to Members of the Scottish Parliament (Seaton, 2000). It does not seek to emulate the accumulated collections of resources in the House of Commons Library but takes full advantage of an internet and intranet platform for the delivery of electronic services. It also has a Library Liaison Officer to maintain relationships particularly with Partner Libraries both to assist in dealing with enquiries about Parliament and for educational purposes. The Scottish Parliament website was an innovation in providing a comprehensive account of all aspects of Parliamentary business, both in the Chamber and committees. It includes forthcoming meetings as well as the full text of all proceedings since May 1999 and a complete archive of all other Parliamentary publications. ${ }^{57}$ The Library of the national Parliament of Ireland, the Houses of the Oireachtas, is in Leinster House; access is restricted to Members of the Oireachtas: Deputies and Senators. A comprehensive website is maintained by the Houses of the Oireachtas. ${ }^{58}$

\footnotetext{
${ }^{56}$ http://www.parliament.uk with the House of Commons Information Office page at http://www.parliament.uk/directories/hcio.cfm

${ }^{57}$ http://www.scottish.parliament.uk/, http://www.wales.gov.uk/, http://www.niassembly.gov.uk/

${ }^{58}$ http://www.oireachtas.ie/
} 


\section{Government Libraries}

In some countries there is a major government law library, such as a library of the Ministry of Justice; these libraries are large legal research libraries and collect considerable amounts of comparative as well as domestic material. Neither the United Kingdom nor Ireland has such a library, perhaps because of the dispersal of responsibility for aspects of the legal system among several government departments (court and parliamentary libraries, which do include major law libraries, are treated separately above). Government libraries hold official publications and basic legal materials within the area of the department's competence, particularly to assist in the preparation of legislation and allow the department's legal advisers to perform research. Government libraries are generally not open to the public; enquiries are sometimes directed to dedicated information hotlines or special public information units, and increasingly to websites.

The Directory of British and Irish Law Libraries (Fothergill, 2002) is a useful first place of reference but more detail can be found in the Guide to libraries and information services in government departments and other organisations (Dale \& Wilson, 2004). The Directory lists in London alone: the Customs and Excise Solicitors Library, the Legal Information Centre of the Department of Work and Pensions, the Foreign and Commonwealth Office (FCO), the Health and Safety Executive, the Home Office Library, the Law Commission, the Lord Chancellor's Department - now the Department for Constitutional Affairs, the Office of Fair Trading, and the Treasury Solicitors Library. Each collects material in its particular area of specialisation and the list is not exhaustive.

The Home Office Library, as an example, is a large library which reported 54 staff in the 2002 Directory and undertakes considerable amounts of research. It is strong in criminal law and holds penal codes and codes of criminal procedure from overseas as well as good collections on criminal justice, criminology, penology, and police studies. An example of new initiatives in information services in government departments is the Crime Reduction Unit of the Home Office which advertises on its website that its Information Services Team "provides a free, open to anyone working in crime reduction, enquiry service and maintains an extensive library of material and has access to databases and other external information resources". 59

In recent years government libraries with large accumulated collections have disposed of considerable amounts of stock which did not serve the working needs of the department; this process often accompanied relocation. The FCO Library maintains collections of international law including treaties and collections of the law of British Overseas Territories. Its magnificent collection of legislation from Commonwealth countries since the earliest colonial times is held in trust by the IALS library and complements the strong Commonwealth law collections there. Large collections of non-legal material were transferred to a range of other university libraries during the early 1990s. More recently the Inland Revenue has disposed of many overseas tax materials to other institutional libraries, retaining working collections of recent materials.

\footnotetext{
${ }^{59}$ http://www.crimereduction.gov.uk/crimereductioncentre22.htm
} 
The library of the Law Commission, which is an independent body keeping the law of England Wales under review and recommending reform, collects Commonwealth law reform publications in particular and is part of the Court Service Library and Information Services.

\section{Collaboration}

One of the watchwords of librarianship is collaboration because no one collection can serve every need of their users. Collaboration is necessary to make the most efficient use of available funds and ensure that no project or initiative unnecessarily duplicates the efforts of another. Librarians need to combine to agree standards of performance and professional behaviour. In technical terms librarians adopt standards by utilising international formats for data, for electronic manipulation of metadata, and for metadata content. Professional librarians have always been convinced of the benefits of collaboration and have often worked hard to convince their institutional management. Networking and the formation of professional associations (see below) are themselves expressions of collaboration and many initiatives and collaborative projects rely on contacts, sometimes on contact between a relatively few people.

BIALL in its second year of existence formed a Committee on Co-operation and the Committee issued a Report in 1971 which remains an impressive document and an agenda for action to improve provision of legal information, (BIALL, 1971). ${ }^{60}$ One can see the origin of most collaborative strategy in the Report since it dealt with a national policy for acquisitions based on centres of excellence, standards for law collections and principles of access, recommendations on exchange of duplicates (the origin of the successful scheme still operated by BIALL), standards for classification and cataloguing of legal materials, an early recognition of the need for coordination in the work of libraries in the harnessing of automation, and training of law librarians.

\section{Collaboration - collections}

The range of printed union lists of legal materials issued by the IALS between the late 1940s and 1987 were staple reference material of their time. They helped law librarians to identify materials and locate holdings for their users and also encouraged coordination in acquisitions. The contacts made in the compilation of these lists also played a part in the growing awareness of the profession.

Today many law libraries have catalogues available on the web and the largest academic libraries contribute records to the joint catalogue of the Consortium of University Research Libraries, COPAC. However, there is no one place easily to ascertain law holdings of libraries across the country. Smaller libraries and private libraries do not necessarily make their catalogues freely available. The value of union lists in facilitating the sharing of legal resources among a group has been recognised by the City Legal Information Group, the Scottish Law Librarians Group, and the BIALL Irish Group.

${ }^{60}$ The Report is described in some detail in Blake (2000, pp. 25-28) 
Collaboration in collection building has been promoted for many years. BIALL advocated on a number of occasions that a national service for rarer materials should be based on established centres of excellence, in particular the IALS Library and the Bodleian Law Library and even that the British Library should help to fund inter-library loans posts at the two libraries. The British Library funded the purchase of foreign law reports at IALS for some years in the 1970 s and early 1980s in recognition of the existing collections and expertise there. The informal collaboration between the British Library and its near neighbour, IALS, over the years was developed into a formal Concordat in 2001 to enhance collaborative collection building and services and training.

The Foreign Law Guide (FLAG) was a major project on collaborative collection management in undertaken from 1999 to 2002 by IALS library, the Bodleian Law Library, the Squire Law Library, the British Library, and the library of the School of Oriental and African Studies. The project produced a major report on academic needs for foreign, comparative and international law materials (Clinch, 2001), created a publicly accessible database of holdings based on a painstaking audit of UK law libraries, ${ }^{61}$ and issued a final report on coordinated collection management (Clinch, 2002). At a similar time another project, CASE, was investigating collaboration between university libraries in the provision of legal research materials within a particular region, Yorkshire and Humberside. $^{62}$ The FLAG project had drawn together the lead institutions to such an extent that they formed the Foreign Law Research group (FLARE) at the conclusion of the project to take forward collaboration and try to ensure coverage of foreign law.

\section{Collaboration - Standards}

BIALL was from the outset concerned that law libraries should collect at least the basic materials of English law and supported applications for financial provision by colleges of education to meet that standard. BIALL set up a SubCommittee on Standards in 1973 and published the BIALL Standards for Law Libraries in 1981 (BIALL, 1981). At that time the emphasis placed on services and staffing levels was in contrast to the other main work on standards by the SPTL.

The SPTL had provided guidance to law schools and law librarians since 1958 through statements of 'minimum holdings' of specified legal publications, which had a significant effect on the expansion of academic law libraries. In 1995, a new Statement of Standards for University Law Library Provision was prepared on behalf of the SPTL by a consultative group comprising all major stakeholders and first published in 1995 with a major research report on law libraries and legal education in the United Kingdom which was funded by the Lord Chancellor's Advisory Committee on Legal Education and Conduct (SPTL, 1995).

The new Statement took account of major changes in university legal education as law schools became more diverse in their resources, missions

\footnotetext{
${ }^{61}$ The searchable database, final report and other documentation are available at http://ials.sas.ac.uk/library/flag/flag.htm

${ }^{62} \mathrm{http}: / /$ case.leeds.ac.uk/
} 
and styles of teaching and more thoroughly monitored and assessed for quality, including the quality of library provision. The standards recognise that a law library is more than collections of information but is a complex operation whose level and quality of services depend on a range of factors. The statement provides a comprehensive set of standards covering all aspects of law library provision from organisational relationship with the law school and staffing to space, equipment, and collections of both print and electronic resources but specifies no single prescription for adequate provision. The standards are accompanied by a detailed commentary incorporating data from the annual survey (Clinch, 2003) to indicate current practice. The Statement was most recently revised in 2003 (SLS, 2003). The SLS, representative of independent academic opinion, is unique in making this continuing commitment to the investigation, analysis, and expression of what is needed for effective library provision for its discipline.

\section{Collaboration - Professional Ethics}

There has been limited engagement by BIALL until recently with the ethical issues relating to the practice of law librarianship (Gordon-Till, 2003). The American Association of Law Libraries (AALL) has issued a statement of ethical principles ${ }^{63}$ and in the UK there is a Statement of Ethical Principles and a more extended Code of Professional Practice promulgated by the Chartered Institute of Library and Information Professionals (CILIP) ${ }^{64}$ The issues for law librarians in Britain and Ireland are addressed later in this volume.

\section{Professional Associations - the British and Irish Association of Law Librarians}

BIALL ${ }^{65}$ is well established as the professional group for law librarians and provides support for all those working with legal materials across the four jurisdictions. The history of the Association has been documented by Mary Blake, its Honorary Secretary from 1976 to 1987 and its Honorary Archivist since that time (Blake, 2000). Membership of BIALL has risen from 47 personal and institutional members in the year of its formation in 1969, to over 300 in 1986 to over 750 at present. ${ }^{66}$

The Association's membership is as diverse as the sector and draws its strength from the diversity of experience which is brought to its activities. At its formation, members were drawn primarily from academic law libraries, libraries of the Inns of Court and the law societies, and from government departments. One obvious trend in membership, apart from the steady increase, has been the increase in the proportion of law firm librarians, after an initial wave of new academic librarians. There was one law firm librarian on the original 1969 list of members, six in 1970, 25 in 1980, 108 in 1988 and now over 350 , about half of the total membership. In a recent BIALL salary survey, only 98 people ( 30 per cent) claimed to be members or fellows of

\footnotetext{
${ }^{63} \mathrm{http}: / /$ www.aallnet.org/about/policy_ethics.asp

${ }^{64}$ http://www.cilip.org.uk/professionalguidance/ethics/

${ }^{65}$ www.biall.org.uk

66 "The Association has continued to increase its membership since its formation without recourse to any intensive recruitment drive" (Blake, 2000, p. 69)
} 
CILIP, although some respondents from Ireland might belong to the Library Association of Ireland (McTavish, 2003, p.19, table 8.22).

BIALL was formed to fill a vacuum in support for those working with legal information. There was no doubt an awareness of the work of the AALL and the International Association of Law Libraries (IALL), itself a result of an initiative from AALL. The famous workshop in Harrogate in February 1968 which led to the foundation of BIALL was organised by Don Daintree of Leeds Library School and arose from the perceived need for training in legal bibliography.

"Following the final talk of the Workshop by Willi Steiner and Betty Moys on the International Association of Law Libraries (IALL) it was resolved to set up a British section, and an ad hoc Committee was appointed to look into the possibility and invite people's views. The members of this committee were Wallace Breem (who volunteered to send a circular to all law libraries), Don Daintree, Betty Moys, Willi Steiner and Derek Way. Replies to the circular were so encouraging that at the second Workshop in April 1969 the Association of Law Librarians was formally established." (Blake, 2000, p.4)

The Association's current constitution including governance and membership is available on its website. ${ }^{67}$ The organisation is managed by a Council comprising an annually-elected Chair, four other elected officers, and five elected Council members, and employs an Administrator. There are standing committees on Legal Information, External Affairs, Conference Organisation, Membership Services, Publications, Professional Standards and Development, Strategy and Finance, a Web Editorial Board, and the Editorial Board of Legal Information Management. This demonstrates the breadth of its activities.

BIALL has no powers to regulate law librarianship but undertakes a wide range of activities to support law librarians, provide opportunities for the discussion of law library work, promote the better administration of law libraries, promote the improvement of the position and qualifications of law librarians, promote and encourage bibliographical study and research, to publish, and to collaborate with other organisations.

BIALL has provided continuing professional development for its members since its inception. There is a major annual study conference held since 1970, currently in June each year, which is now attended by over 400 people, supplemented by a pre-conference workshop. There is also an annual study weekend normally held in November. There are short courses such as a regular one-day course in 'legal reference materials' and various specialist courses, visits, and a longer course of weekly lectures over a period of months on 'law for law librarians' in conjunction with the University of Westminster which began in 1984. The Association administers, through its External Affairs Committee, several bursaries to provide financial assistance

\footnotetext{
${ }^{67}$ http://www.biall.org.uk/docs/Regulations.pdf
} 
for members to attend its own conference and to attend conferences overseas.

BIALL has published a journal, Legal Information Management, formerly the Law Librarian, since 1970 and issues a quarterly newsletter for members available in electronic and print form. The Association has published the leading work on law librarianship in Britain and Ireland, The Manual of Law Librarianship, of which this volume is the successor, in two editions (Moys, 1976; Moys, 1987). The Directory of British and Irish Law Libraries, first published in 1976, is now in its seventh edition and is an indispensable reference work (Fothergill, 2002). The Association does not publish a membership list, although one did appear among the AGM papers until 1979 and subsequently appeared in the Law Librarian during the first half of the 1980s. The annual BIALL Salary Survey (McTavish, 2003) has developed into a sophisticated statement of the profession in terms of age, experience, and geographical and sectoral spread, as well as a tool for ascertaining best practice in rewards.

The Association has issued a range of other publications over the years including a timely bibliography of Community law (Lutyens, 1973), an Index to Legal Essays 1975-79 (Tearle, 1983), Standards for Law Libraries (BIALL, 1981), the Bibliography of Commonwealth Law Reports (Breem \& Phillips, 1991), Sources of Biographical Information on Past Lawyers (Holborn, 1999), the History of the British and Irish Association of Law Librarians 1969-1999 (Blake, 2000), and a series legal research training packs. (BIALL 2000, 2003). The Association, in addition to its own publishing, has sponsored or funded research including a survey of academic law libraries and a survey of trends in legal information provision. The Association also operates a duplicates exchange scheme to allow unwanted stock to be transferred to more appropriate libraries.

The Wallace Breem Memorial Award, sponsored by the Inner Temple and BIALL, is designed to recognise excellence through contributions to law librarianship, or provide financial assistance for special research or other projects at doctorate level or above. The Award was inaugurated in 1990 in memory of Wallace Breem, former librarian of the Inner Temple Library and a founder member of BIALL (Noel-Tod, 1990). The Willi Steiner Memorial Lecture was set up in 2004 by the Association in memory of Willi Steiner, an outstanding member of the law library profession, librarian of two outstanding law libraries, the Squire Law Library in Cambridge and the IALS in London and a founder member of BIALL (Winterton, 2003).

BIALL, among many other activities, has a strong interest in the public policy arena but has never been able to emulate the participation in advocacy, lobbying and policy-making at regional and national level achieved by the much larger AALL. BIALL has in the past submitted responses to various official enquiries including submissions to the British Library, the University Grants Committee, the Royal Commission on Legal Services, the Law Society and the Lord Chancellor's Advisory Committee on Legal Education and Conduct. It has responded to proposals for changes to copyright legislation in 
the past but these issues are now increasingly decided on a global stage.

\section{Other Professional Associations of Law Librarians}

There is a range of other groups within Britain and Ireland providing support and networking for law librarians in geographical areas, regions and cities, or concerned with particular subjects, or in similar law libraries (for example the BIALL One Man Band / Small teams Group). Many members of such groups are law firm librarians although others from the Court Service, barristers' chambers, local law societies, and accountants also belong. These groups are often not explicitly affiliated to BIALL and are financially independent and self-sustaining but all maintain co-operation with BIALL, with which they share many of their members. There is a list of groups on the BIALL web site and a few are noted under member libraries in the Directory of British and Irish Law Libraries and in the A History of the British and Irish Association of Law Librarians (Blake, 2000, pp. 86-88).

The City Legal Information Group (CLIG), ${ }^{68}$ formerly City Law Librarians Group, was established in 1975 and has over 300 members. It is one of the earliest specialist groups and one of the most prominent with a fine web site and a tradition of collaboration despite the intense competition of members' employers. An early project was a union list of law reports and serials held by its members. It provides both educational and social events convenient for legal information professionals in and around the City of London.

Groups based on geographical area offer a range of events which supplement those arranged by BIALL and form a focus for local issues. The groups include the Scottish Law Librarians Group established in 1988 which has issued a Directory (Wilcox, 1995) and a union list of serials (Wilcox, 1997), the BIALL Irish Group formed in the late 1980s which issues a union list (Clavin, 2000), ALLICE (Association of Law Librarians in Central England) established as the Birmingham Association of Law Librarians in 1987, BRILL (Bristol Law Librarians Group) established in 1989, Cardiff Law Librarians Group established in 1989, Leeds Law Librarians Group established in 1990, Manchester Legal Information Group established in 1990. The Newcastle Law Librarians Group was established in 1990 and, reflecting the diversity of the group and their work, it has been renamed B-LINE: Business \& Legal Information Network.

Groups based on subject areas include government, insurance, business information, and specialised subjects such as property legal information. The European Information Association ${ }^{69}$, formerly the Association of European Documentation Centre Librarians, though accommodating interests much wider than law, has produced many useful publications and run courses relevant for law librarians.

There are national or regional associations of law librarians in the USA, Canada, Australia, New Zealand, Germany, the Netherlands, the Nordic

\footnotetext{
${ }^{68} \mathrm{http}: / /$ www.clig.org/

${ }^{69} \mathrm{http}: / / \mathrm{www}$.eia.org.uk/
} 
countries, Switzerland, Japan, Nigeria, South Africa, the Philippines, and the Caribbean. These associations are listed on the BIALL website ${ }^{70}$ and more comprehensively on the University of Chicago Law School site. ${ }^{71}$

The American Association of Law Libraries is by far the largest and oldest law library association, founded in 1906, with a membership of over 7,000 and an annual meeting that attracts over 2,000, including a small contingent from Britain and Ireland each year. It publishes the quarterly Law Library Journal and a monthly magazine AALL Spectrum. Membership of AALL and attendance at its conference no doubt inspired some of those who founded BIALL.

The International Association of Law Libraries, founded in 1959, is a worldwide organization dedicated to bringing together and facilitating the work of law librarians who use foreign and international legal resources. It publishes the International Journal of Legal Information and holds an annual course in international law librarianship. The courses do not address transferable skills and other areas generally covered at the conferences of national associations; they address aspects of foreign and international legal systems both in substance and in their expression in legal information, seeking to give an understanding of the law underlying the information.

\section{Professional networking in Britain and Ireland}

Professionals form communities of practice to share knowledge and skills both through personal contacts and through the formation of professional bodies such as those described above. Networking is an enjoyable and important part of professional life.

Networking can start at home and can be virtual. Many people participate through electronic lists and discussion groups, joining associations and reading their publications, and building up contacts by email. Discussion lists provide much needed expertise, support and the mobilisation of opinion. lislaw is the most commonly used electronic discussion list for law librarians in Britain and Ireland. It is hosted by Jiscmail, an agency of the joint funding councils of UK universities, which offers web-based list management and maintains archives of messages posted. ${ }^{72}$ The list has about 770 members mainly based in Britain and Ireland. There are many specialised lists and in fact there are so many lists that there is a searchable list of lists in order to identify relevant one for your purpose. ${ }^{73}$ BIALL, in common with many associations, has a list open to its members only.

\footnotetext{
${ }^{70}$ List of national and international law library associations compiled by the British and Irish Association of Law Librarians, www.biall.org.uk See 'International Law Library Associations' on the 'links' page

${ }^{71}$ List of national and international law library and related associations compiled by Lyonette Louis-Jacques, Foreign and International Law Librarian and Lecturer in Law, D'Angelo Law Library at the University of Chicago Law School www.lib.uchicago.edu/ Ilou/iall.html

${ }^{72} \mathrm{http}: / / \mathrm{www}$.jiscmail.ac.uk

${ }^{73}$ Lyonette Louis Jacques has her latest list of lists for law librarians at http://www.lib.uchicago.edu/ Ilou/lawlists/lawlibs.txt which also gives advice on tracking lawrelated lists
} 
Conferences, such as the annual study conference of BIALL, often give you an insight into other approaches to law librarianship, perhaps the philosophical underpinnings of our profession or perhaps a good solution to a particular problem, a new way of expressing one's aspirations or a simple new procedure. Conferences of other organisations such as the SLS, the Society of Computers and $\mathrm{Law}^{74}$ or of practising lawyers can be equally rewarding.

\section{International Networking}

Law librarians increasingly need to be aware of foreign and international legal systems, understand the sources of law, and have recourse to expertise beyond local resources. Today there is not only a growth of transborder economic activity, but every aspect of law is affected by the interconnected nature of our world. International contacts not only broaden our horizons and make us aware of other legal systems and responsive to enquiries about them; contacts also give us back-up for materials, language and expertise (Winterton, 2004).

Conferences overseas are opportunities to build those contacts. There is an international calendar of events on the IALL website and it also appears in the International Journal of Legal Information. Most of the national and regional associations hold a regular conference. Since 1998 the American, British and Irish, and Canadian associations, now joined by the Australian Law Librarians Group, have held a biennial Joint Study Institute to cultivate interchange and give an opportunity to learn about the legal system, heritage and traditions of the host countries. The IALL conference is in a different country each year and over the past few years has taken place at the Bar Council of Ireland in Dublin, at the Swiss Institute for the Comparative Law in Lausanne, at Yale Law School with an additional program at Harvard Law School, and at the University of Cape Town.

The conference of the International Federation of Library Associations is a massive meeting and not one which concentrates on law librarianship. There is a session each year to bring law library matters to the attention of a wider audience of librarians in different sectors, traditionally arranged by the IALL. However, the importance of IFLA is its role in international policy issues, such as intellectual property and international trade, which now impinge on all libraries so strongly. A law library association discussion group has been formed under the auspices of IFLA to facilitate international networking at a strategic level and this may offer us all a stronger voice in advocacy at an international level. These issues are addressed for AALL by Robert Oakley (Oakley, 2003).

BIALL has, with the financial assistance of law publishers, sent an official representative to the conferences of overseas law library organisations and has also offered bursaries to its members to attend an overseas conference since the early 1990s. IALL maintains a scholarship program not limited to association members to provide financial assistance for law librarians to attend its conferences.

\footnotetext{
${ }^{74}$ http://www.scl.org
} 
An extended visit to a library in another country can provide a more immersive experience than a conference and potentially a much more valuable experience. The IALS has a Visiting Fellowship in Law Librarianship which brings eminent overseas law librarians to London and they have given seminars and often spoken at the BIALL Conference. There is no formal programme for job exchanges with overseas law librarians although AALL maintains a clearinghouse of information on job exchange ${ }^{75}$ and IALL is investigating a programme of placements and internships.

\section{Law Librarianship}

Law librarianship has been an increasingly attractive career with the expansion of law libraries since the mid-1970s, especially in law firms and a recent survey appears to provide reassurance that employment in the academic law library sector is at least stable (Young, 2002). Despite the effects of downturns in the economy, advertisements for law librarians have generally figured prominently and in large numbers in 'Appointments', the recruitment section of the Library + Information Gazette, ${ }^{76}$ over the past twenty years and numbers in the profession have risen as the membership of BIALL demonstrates.

The annual BIALL Salary Survey gives a detailed statistical account of the employment of law librarians in Britain and Ireland (McTavish, 2004). The latest survey for 2002/03, which received 343 responses of which 160 were from law librarians in London, reports salaries for full-time librarians ranging from $£ 12,750$ to $£ 68,000$ with a median of $£ 27,156$ ( $£ 24,900$ in central and local government, $£ 29,000$ in the academic sector, $£ 27,273$ in law firms, $£ 31,795$ in professional bodies, and $£ 39,750$ in the in-house sector). Salaries are analysed by a large number of factors including location; the highest salaries of statistical significance are paid in the City of London (a median salary of $£ 30,000$ ) and the lowest salaries in North England and Scotland (a median salary in the region of $£ 20,700$ ). Generally those employed in law libraries are graduates with library and / or information qualifications, predominantly postgraduate LIS qualifications. Of the 279 full time employees who responded (of whom 83 per cent were female), 262 had a LIS qualification, but only 30 had a law degree (less than 11 per cent).

There are no specialist qualifications in law librarianship although several library schools offer specialist options in legal information as part of their programmes. At the University of Aberystwyth, for example, it is possible to combine information management with law as a joint honours degree. There has been, since the establishment of BIALL, continuing professional education available for law librarians, but no formal system of the type introduced by the legal profession and recently proposed by CILIP.

There has been scope for lateral movement and increase in salary for successful law librarians, particularly in the law firm sector. There has

\footnotetext{
${ }^{75}$ http://www.lawsch.uga.edu/fcil/clearintro.html

${ }^{76}$ Published by CILIP, formerly entitled the Vacancies Bulletin of the Library Association, and more recently online in Lisjobnet, http://www.cilip.org.uk/jobscareers/lisjobnet/default.htm
} 
generally been rather less mobility between sectors. Perhaps not surprisingly the larger law libraries, which have a staff structure which allows for a career progression, also participate in training both by taking graduate trainees before they attend library school and by providing approved training schemes for career entrants after library school. The IALS Library, the Law Society Library, and the Inns of Court libraries have acted as feeder libraries for those entering the profession.

There is a small number of senior and prestigious posts in law libraries but, as noted in the previous edition (Logan, 1987, p. 32), they are so few in number that they can scarcely be said to represent realistic career goals. In such posts, management skills become as important as specialist knowledge of legal information. Subject librarians engaged in day-to-day reference work in law may find it difficult to gain sufficient experience of management to achieve the most senior posts. If achieved, a blend of management and subject work may provide great satisfaction but it is often difficult to tackle the one while maintaining the other. Those who gain sufficient management expertise may move out of law libraries because opportunities in Britain and Ireland for further advancement in law libraries are limited.

\section{The Future Role of Law Librarians}

The impact of digital technology is mutating traditional models of information management. This goes far beyond difficult questions of collection development regarding format of material to be acquired and what particular nature of hybrid library to adopt at a particular time. It involves a redefinition of the role of law librarian (Danner, 1998; Susskind, 1999).

There has been a dramatic vertical integration of the processes of communication. Digital technology has allowed publishers to perform some functions of traditional libraries in the storage and delivery of information since it allows the publication of far more material than a system based on the traditional printed medium and it also allows delivery direct to the researcher. Long-term preservation of information which was once the role of libraries now needs to be addressed at the birth of digital material and cannot be separated from its production, throwing the responsibility onto the producer, whether commercial or institutional.

During these changes, which might threaten the existence of libraries in the traditional sense, new opportunities have arisen for law librarians. Aspects of the work of law librarians can be identified in the capture and description of content, more sophisticated management of resources, in aspects of the publishing of information, in retrieving and packaging information for research, and in education and training.

The paradigm shift in the role of law librarians is exemplified in law firm libraries which are dynamic environments for the management of information rather than repositories of material; see Mansfield (1999) and McTavish \& 
Duggan (1999). ${ }^{77}$ The opportunities of emerging roles in information and knowledge management are accompanied by needs for re-skilling and by potential threats as the boundaries between roles of law librarians and practitioners become less well-defined. Some aspects of the role of the professional support lawyer may suggest the emergence of a true hybrid post combining legal and information skills but this remains unproven and most firms do not presently require an information management qualification for those posts.

Although issues of disintermediation will continue to concern libraries as services are delivered and marketed directly to end-users, law librarians are taking responsibility for the management of increasingly broad definitions of information in a trend likely to reinforce the intermediary function. This may be seen as an extension of the traditional role of selecting and organising content. Librarians are involving themselves further up the communication chain in the creation of information products; they capture content, organise it, and make it available internally or externally on the Internet, taking over some roles of publishers. Librarians are also involving themselves further down the communication chain by processing information for particular uses and by assisting and training end-users in using information. These roles may be an extension of the traditional role of advising the reader and may take the form of training in research skills, creating virtual learning or research environments, or undertaking the research and pre-processing of information which amounts to part of the end-user's work. Roles including legal information officer, knowledge manager, publisher and teacher will require increasing subject expertise, increasing collaboration with others, a blurring of the boundaries of their roles and the roles of users, and an evolving range of skills and attitudes.

\section{The Future of Law Libraries}

The future of law and Transforming the law (Susskind, 1998 and 2000) are among the best known writing in the United Kingdom about the future development of the law and the legal profession. There are major pieces of research by law library organisations about the future of their profession. Law and order: trends in legal information provision is a study for BIALL of the key issues in the management and provision of legal information within the United Kingdom and Ireland BIALL (McTavish \& Ray, 1999). Beyond the boundaries, is a report by the AALL Special Committee on the Future of Law Libraries in the Digital Age which contains the most comprehensive analysis of issues surrounding the evolution of virtual and physical law libraries in all sectors in the USA (AALL, 2002). The findings and conclusions are summarised below.

In a period of rapid change, law librarians will continue to be flexible in serving lawyers and their parent organisations and innovative in defining the direction and boundaries of their mission. Law librarians will continue to balance a strong commitment to the legal system and the legal profession with a professional allegiance to the wider librarianship community. It is likely that

\footnotetext{
${ }^{77}$ Shona McTavish of Northumbria University has since continued her research into information management and information use in law firms. Changes in the role of academic law librarians are explored in Rudge \& Andrews (2000).
} 
law librarians will work more closely with other information workers and become part of larger structures. Although libraries serving the different sectors of the legal system will continue to develop differently and offer different levels and styles of services, common development themes can be discerned.

The strategic drivers for change operating on law libraries can be grouped into those centred on: legal publishing, the nature of access to legal information, preservation, authentication, intellectual property law and licensing, user expectations, information, and communications technology, with globalisation playing a part in each (AALL, 2002, p. 3).

In commercial publishing the transition from print to electronic and the consolidation of publishing companies will continue. There will be considerable emphasis on customisation and personalisation of information products, embedding them within the workflow, aiming at the level of integration and market saturation achieved by Microsoft. There will be competition between commercial publishers and a growing number of noncommercial and free-to-Internet sources of information and increasing pressure on commercial companies to demonstrate real added value. Government delivery of information and services by electronic means will extend greatly. However, in terms of access to legal information, the digital divide both within Britain and Ireland and internationally will be an increasing concern.

Information and communications technology continues to evolve at a very rapid pace. While developments in electronic legal publishing tend to reduce the amount of clerical work in maintaining an up to date collection, other demands are being made which require higher skills. Law libraries not only need to be provided with support and development potential by their parent organisation but also need in-house expertise among their staff as they build their intranets, extranets, and portals.

The concern over the preservation of the print record and the born-digital record of the law will continue after the present period of transition with its inadequate measures for electronic record management. The need for limited numbers of print repositories will need to be considered. The issue of permanent URLs will need to be addressed or much of the work of cataloguing and evaluating materials on the web will become unsupportable. Born-digital materials will require more rigorous authentication which was unnecessary for print materials. New models of publishing will require content creators to assign citations at the point of creation rather than publication, as the English courts have now started to do.

As libraries license content for access rather than owning content, their control over access becomes more stringently limited by private agreement rather than public law. The plethora of license agreements under different terms for different materials and different users may be managed by sophisticated technology based on user identity and status but strikes against the some of the values of libraries and against practices of scholarship in the 
discovery of new relationships between unsought materials. The expansion of copyright protection and reduction of fair dealing, database protection, and the general absorption of scholarly material under the same terms as publishing of entertainment media will impact on many libraries and their users adversely.

User expectations have always driven libraries and in future there will be an expectation that all information should be accessible at any time and in any place. Remote twenty-four hour access has or will become a legitimate expectation of many users and, depending on licence restrictions and therefore on budget, this will be possible. However, greatly increased training both in individual systems and general information management will be required in order for users to fulfil their expectations of the efficiency of modern searching and to enhance critical awareness of the relative value of information retrieved.

Law libraries will operate increasingly in a virtual environment and the library as a physical space will change. However, librarians and their users still generally believe that the hybrid library environment of both electronic and print, to different degrees in different sectors, will remain the dominant model for many years. ${ }^{78}$ The library is likely to remain, certainly in collegiate environments, a physical focus of the institution, and the librarian, even as manager of a virtual law library, will need to provide the human interface. ${ }^{79}$

\section{Further Reading}

Abel, Richard L. (1988), The legal profession in England and Wales, Oxford: Basil Blackwell

Abel, Richard L. (2003), English lawyers between market and state, Oxford: Oxford University Press

American Association of Law Libraries (2000), Leadership for the $21^{\text {st }}$ Century: new realities, new roles, Chicago: AALL

American Association of Law Libraries. Special Committee on the Future of Law Libraries in the Digital Age. (2002), Beyond the boundaries: Report of the Special Committee..., Chicago: AALL

Baker, John H (2000), 'The third university of England' in J. H. Baker (ed.), The common law tradition: lawyers, books and the law, London: Hambledon Press, pp. 3-28

Baker, John H. (2002), An introduction to English Legal History. $4^{\text {th }}$ edn., London: Butterworths

Ballantyne, G.H. (1971), 'The Signet Library, Edinburgh', Law Librarian, 2, pp.3-5,15

Ballantyne, G.H. (1979), The Signet Library Edinburgh and its librarians, 1722-1972, Glasgow: Scottish Library Association

\footnotetext{
78 "The concept of the hybrid library emerged as the most realistic future library scenario during the discussion; most of the listserv participants did not envision an entirely digital law library - no matter what type of law library." (AALL, 2002, p. 63)

79 "The virtual law library offers many opportunities and challenges and we will each see our world changing to take advantage of these. Librarians can cement their roles in the virtual library by ensuring that the clients never forget that the human component is integral to any library, virtual or physical." (Whelan, 2001, p. 16)
} 
Best, K. (1983), 'The Supreme Court Library', Law Librarian, 10, p. 13.

Birks, Peter (ed.) (1994) Reviewing legal education. Oxford: Oxford University Press.

Birks, Peter (ed.) (1996), What are law schools for? (Pressing problems in the law, vol.2), Oxford: Oxford University Press

Blake, Mary (2000), A history of the British and Irish Association of Law Librarians 1969-1999. Warwick: BIALL

Breem, Wallace and Sally Phillips (eds) (1991), Bibliography of Commonwealth law reports. London: Mansell

British and Irish Association of Law Librarians. Committee on Co-operation (1971), Report of the Committee on Co-operation, London: BIALL.

British and Irish Association of Law Librarians. Sub-Committee on Standards. (1981), Standards for law libraries. London: BIALL. Appendices VI - XI (Recommended holdings for law libraries) were published as The Law Librarian, special Issue, January 1983

British and Irish Association of Law Librarians (1985), 'National provision for legal information', Law Librarian, 16, p. 70

British and Irish Association of Law Librarians (2000), Legal research self-test questions and answers: part 1: legislation, cases, Internet, Warwick: BIALL.

British and Irish Association of Law Librarians (2003) Legal research training pack: Part 2: Corporate, European Union, Property, Warwick: BIALL

British Library Working Party on Provision for Law ([1985?), Report, London: British Library

Byrne, Margaret (2002, 'The Law Society library' in Hall, Eamonn G. and Daire Hogan (eds) (2002), pp. 197-208

Cadell, P. and A. Matheson (eds.) (1989), For the encouragement of learning: Scotland's National Library 1689-1925, Edinburgh: HMSO

Cheffins, Richard (1999), 'National legal collections: the British Library', Law Librarian, 30, pp. 63-65

Clavin, Jane (2000), Union list of legal periodicals and related stock in Irish libraries, $4^{\text {th }}$ ed., Dublin: British and Irish Association of Law Librarians

Clinch, Peter (2001), 'FLAG Project: survey results', Legal Information Management, 1, pp. 45-58

Clinch, Peter (2002), 'FLAG the new internet gateway to foreign law holdings in UK national and university libraries', Legal Information Management, 2, pp. 37-39. Also available at http://www.IIrx.com/features/flag.htm

Clinch, Peter (2003), 'SLS/BIALL academic law library survey 2001/2002', Legal Information Management, 3, pp. 107-118

Committee on Legal Education (1971), Report, Cmnd. 4595, London: HMSO (Ormrod Report)

Committee on the Future of the Legal Profession (1988), A time for change, London: General Council of the Bar and The Law Society (Marre Report)

Constitutional Reform: a Supreme Court for the United Kingdom. (2003), Department for 
Constitutional Affairs consultation paper, London: HMSO

Daintree, D. (1976), 'Law libraries and their users', in Elizabeth Moys (ed.), Manual of law librarianship. London: André Deutsch, pp. 31-58

Daintree, Don (1983), 'Law libraries in the United Kingdom', in Law librarianship: a handbook vol. 2, edited by H. P. Mueller and P. E. Kehoe, Littleton, Col.: Rothman for AALL, pp. 819851

Dale, Peter and Paul Wilson (2004), Guide to libraries and information services in government departments and other organisations, $34^{\text {th }}$ edn., London: British Library

Danner, Richard (1998), 'Redefining a profession', Law Library Journal, 90, pp. 315-356

Dicey, A. V. (1883), Can English law be taught at the universities? London: Macmillan

Donnelly, J. (1996), 'The Judges' Library, Dublin', Law Librarian, 27, pp.152-155

Fothergill, Pauline (ed.) (2002), Directory of British and Irish Law Libraries, $7^{\text {th }}$ edn. [Warwick]: British and Irish Association of Law Librarians

Gordon-Till, Jonathan (2003), 'A code of ethics for BIALL', Legal Information Management, 3, pp. 38-43.

Goudy. Henry (1909), Introductory address to the Society of Public Teachers of Law in England and Wales delivered at the first annual general meeting. London: SPTL

Hall, Eamonn G. and Daire Hogan (eds) (2002), The Law Society of Ireland 1852-2002: portrait of a profession, Dublin: Four Courts Press

Harris, Phil and Steve Bellerby (1993), A survey of law teaching 1993. (Association of Law Teachers Research Project on Legal Education), London: Sweet \& Maxwell

Hogan, Daire (1986), The legal profession in Ireland 1789-1922, Dublin: Incorporated Law Society of Ireland

Holborn, Guy, 'Lawyers and their libraries since 1850', in Peter Hoare \& Alastair Black (eds.), A history of libraries in Britain and Ireland, vol. 3, Cambridge: Cambridge University Press, forthcoming (ca, 2005)

Holborn, Guy (1999), Sources of biographical information on past lawyers, Warwick: BIALL Institute of Advanced Legal Studies. Policy Review Sub-Committee (1986), Report, London: IALS. Chairman: Sir Robert Megarry

John, C. (1992), 'The Advocates' Library three hundred and ten years on', Law Librarian, 23, pp. $111-114$

Jones, David L. (1998), 'The House of Lords Library', Law Librarian, 29, pp.105-107

Kenny, C. (1992), King's Inns and the kingdom of Ireland: the Irish 'Inn of Court' 1541-1800, Blackrock: Irish Academic Press in association with the Irish Legal History Society The Law Librarian vols.1-30, 1970-2000. London: Sweet \& Maxwell for the British and Irish Association of Law Librarians

Law Library of Congress (1982), Law Library 1832-1982: a brief history of the first hundred and fifty years. Washington, DC: Law Library of Congress

Legal Information Management, vol.1- , 2001- . Cambridge: Cambridge University Press for the British and Irish Association of Law Librarians (Sweet \& Maxwell until Winter 2003) 
Logan, Robert G. (1987), 'Law libraries and their users', in Elizabeth Moys (ed.), Manual of law librarianship. $2^{\text {nd }}$ edn. London: Gower, pp. 3-37

Lord Chancellor's Advisory Committee on Legal Education and Conduct. (1996), First report on legal education and training, London: the Committee

Lutyens, Charlotte Rosa et al. (1973), Community law: a selection of publications on the law of the European Economic Community and the relevant law of the original member states, London: BIALL

Mansfield, Susan (1997), Access to legal information in public libraries: a case study in East Kilbride, Glasgow, and Paisley. Unpublished MSc Dissertation, Department of Information Science, University of Strathclyde.

Mansfield, Susan (1999), 'Role of legal information professionals in law firms' in A. J. Kinahan (ed.), Now and Then, London: Sweet \& Maxwell, pp. 127-138

Marsh, S. B. (1990), A history of the Association of Law Teachers: the first twenty-five years. [1965-1990], London: Sweet \& Maxwell

Martin, Ruth. (2001), 'Local law societies: what's in a name?', Legal Information Management, 1, pp. $26-28$

McTavish, Shona and Fiona Duggan. (1999), 'Law firm libraries in Britain and Ireland', Law Librarian, 30, pp.56-63

McTavish, Shona and Kathryn Ray (1999), Law and order: trends in legal information provision, London: Sweet \& Maxwell for BIALL

McTavish, Shona (2003), BIALL salary survey 2002/03 compiled on behalf of BIALL by Shona

McTavish, Information and Communication Studies, School of Informatics, University of Northumbria. Warwick: BIALL

Miskin, Christine (1981) Library and Information services for the legal profession, (British Library Research and Development Reports, no.5633), Boston Spa: British Library Lending Division

Moys, Elizabeth (ed.) (1976), Manual of law librarianship, London: André Deutsch.

Moys, Elizabeth (ed.) (1987), Manual of law librarianship, $2^{\text {nd }}$ edn., London: Gower

National legal collections (1999), 'Historical co-operation' by David Wills; 'Funding cooperation among university libraries' by Jules Winterton; 'Future co-operation' by Barbara Tearle. Law Librarian, 30, pp. 65-71

Neylon, M. J. (1973), 'King's Inn Library, Dublin', Law Librarian, 4, pp. 3-4

Noel-Tod, Alex (1990), 'Wallace Wilfred Swinburne Breem 1926-1990', Law Librarian, 21, pp. 59-61

Oakley, Robert L. (2003), 'International public policy and libraries. Members' briefing on international policies', AALL Spectrum, 8 (3), December, centre insert pp. 1-4

Pound, R. (1953), The lawyer from antiquity to modern times. St Paul, MN: West, pp. 215-219

Pue, W.W. (1989), 'Guild training vs. professional education: the Committee on Legal

Education and the Law Department of Queen's College, Birmingham in the 1850s.', American Journal of Legal History, 33, p. 241-287 
Royal Commission on Legal Services, (1979), Report, London: HMSO (Benson Report)

Rudge, Sarah and Catherine Andrews (2000), 'The electronic saga: the changing role of the law librarian', 31, Law Librarian, pp. 239-242

Seaton, Janet (2000), 'SPICe - breaking new ground', Law Librarian, 31, pp. 104-107

Smith, Hilary. (2000), 'EU information at the Law Society', Law Librarian, 31, pp. 11-13

Society of Legal Scholars (2003), 'A library for the modern law school: a statement of standards for university law library provision in the United Kingdom - 2003 revision prepared by the Libraries Committee of the Society, Convener: Jules Winterton', Legal Studies, 23, pp. 690-710. Also at http://www.legalscholars.ac.uk/documents/standards2003.pdf

Society of Public Teachers of Law [no date], Handbook of the legal curricula pursued at the various centres of public legal education in England and Wales. London: SPTL

Society of Public Teachers of Law (1968), The Society's evidence to the National Libraries Committee. Journal of the Society of Public Teachers of Law, X, pp. 87-90

Society of Public Teachers of Law (1995), 'A library for the modern law school: a statement of standards for university law library provision in England and Wales', Legal Studies special issue. (Includes an introduction by the then Convener of the SPTL Libraries Committee, Terence Daintith, the Statement of Standards, and the detailed research report compiled by Dr. Peter Clinch. The 1995 version of the standards and the various later revisions are also available at http://www.legalscholars.ac.uk.)

St. Clair, J. \&. R. Craik (1989), The Advocates' Library: 300 years of a national institution 1689-1989, Edinburgh: HMSO

Stevens, Robert (1983), Law school: legal education in America from the 1850s to the 1980s, Chapel Hill and London: University of North Carolina Press

Susskind, Richard (1998), The future of law, rev. ed., Oxford: Clarendon Press

Susskind, Richard (1999), 'The future of the law librarian: an interview with Richard Susskind', 30, Law Librarian, pp. 147-154

Susskind, Richard (2000), Transforming the law: essays on technology, justice and the legal marketplace, Oxford: Oxford University Press

Symposium on Law Libraries (1964), 1: Law Libraries by K. Howard Drake; 2: The new Bodleian Law Library at Oxford by P. B. Carter; 3: The Squire Law Library at Cambridge by W. A. Steiner, Journal of the Society of Public Teachers of Law, VIII, pp. 71-88

Tearle, Barbara (ed.) (1983), Index to legal essays: English language legal essays in festschriften, memorial volumes, conference papers and other collections, 1975-1979, London: Mansell

Twining, William (1994), Blackstone's tower: the English law school, London: Sweet \& Maxwell (the 1994 Hamlyn Lectures)

Whelan, David (2001), 'Virtual law librarian: adding value in a virtual world', Chicago Association of Law Librarians Bulletin, 180, Spring 2001, p. 16. Also at http://www.ofaolain.com/resources/articles/virtlawlib

Wilcox, Christine (1997), Union list of periodical and law report holdings, Edinburgh: Scottish Law Librarians Group 
Wilcox, Christine (1995), Directory of Law Libraries in Scotland, $2^{\text {nd }}$ edn., Edinburgh, Scottish Law Librarians Group

Wilson, J. F. (1966), A survey of legal education in the United Kingdom, London: Butterworth, reprinted from (1966) Journal of the Society of Public Teachers of Law, New Series 9, pp. 1144

Wilson, J. F. and Marsh, S. B. (1975) A second survey of legal education in the United Kingdom, London: Butterworth reprinted from (1975) Journal of the Society of Public Teachers of Law, New Series 13, pp. 239-331 and Supplement no.1, London: Institute of Advanced Legal Studies in 1978 and Supplement no.2, London: Institute of Advanced Legal Studies in 1981

Wilson, John (1993), 'A third survey of university legal education in the United Kingdom', Legal Studies, 13, p. 143-182

Winterton, Jules (2003), 'In celebration of Willi Steiner', Legal Information Management, 3, pp. $140-149$

Winterton, Jules (2004), 'The way of ignorance. Members' briefing on international networks', AALL Spectrum, 8 (6), April, centre insert pp. 1-4

Young, Helen (2002), 'Law librarians' survey: are academic law librarians in decline?', 2, Legal Information Management, pp. 50-55 